\title{
MIKROTONÁLNÍ HÁBA: PĚT POZNÁMEK K HÁBOVU KOMPOZIČNÍMU STYLU
}

\begin{abstract}
Alois Hába byl od počátku svého působení, během aktivních let i po své smrti ve všech pracích domácího a zahraničního původu, považován za jednoho z nejodvážnějších experimentátorů hudby 20. století. Obvykle se uvádí, že byl neúnavným propagátorem čtvrttónové a atematické hudby. Pouhé konstatování ovšem ještě přesně nevystihuje obsah a vlastně problematizuje skutečnou koncepci Hábovy hudby, nebot' skladby komponované v nezvyklých tónových systémech představují necelou třetinu Hábova znějícího díla. Autor této studie se zaměřuje na některé mikrointervalové skladby a pokouší se upozornit na skutečnost, že rovněž zde se vedle vlastní kreativní syntaxe významně uplatňují obecné harmonické modely, intervalové kombinace či jiné typizované obraty. Přesto rovněž v Hábově př́ípadě platí, že substanci hudební tradice vytváří znějící dílo a nikoli pravidla, podle kterých jsou skladby sestaveny.
\end{abstract}

1.

První skupinu děl v tradičním tónovém systému tvoří skladby komponované během vídeňského pobytu a pod odborným dohledem učitele Franze Schrekera. Jsou dokonalým obrazem toho, jak v poměrně krátké době Hába ovládl tradiční kompoziční kánon. ${ }^{1} \mathrm{O}$ jejich kvalitě vypovídá rovněž fakt, že s výjimkou první z nich byly všechny nedlouho po svém vzniku (a s vydatnou Schrekrovou pomocí) publikovány v nakladatelství Universal Edition. Rozdíl mezi těmito a dř́ívějšími díly, jež vznikla pod vedením Vítězslava Nováka, je patrný. Dokladem Schrekerova příznivého vlivu jsou dochované autografní skici. Již tištěné vydání Variací na kánon Roberta Schumanna op. 1b se v mnohém odchyluje od rukopis-

1 Jedná se o skladby od op. 1b až k op. 5; Tři fugy pro klavír (s. op., 1918), Variace na kánon Roberta Schumanna op. 1b (1918), Dva kusy pro klavir op. 2 (1918), Sonátu pro klavír op. 3 (1919), Smyčcový kvartet č. 1 op. 4 (1919), orchestrální Ouverturu op. 5 (1920), původně označenou jako Frühlingsouvertüre (Jarní předehra), kterou Hába u Schrekera absolvoval. 
né podoby. Některé části se $\mathrm{v}$ závěrečné verzi neobjeví vůbec, jiné jsou významně přepracovány. Schrekerův autorský podíl je patrný také u Smyčcového kvartetu č. 1 op. 4 (1919). Zde rukopisné varianty prozrazují obvyklou praxi, kdy učitel svému žákovi vrací jednotlivé úseky či věty k přepracování. Konečná úprava podtrhuje princip pevné formální výstavby a motivické vázanosti. Patrná je rovněž zesílená vazba mezi jednotlivými hlasy a melodický proud či větší harmonická rafinovanost.

Smyčcový kvartet, v daných poměrech preferované obsazení s pevnou žánrovou pozicí, umožnil Hábovi do budoucna projekci nejrůznějších kompozičních řešení, jak dokazuje již následující Smyčcový kvartet op. 7, komponovaný ve čtvrttónové soustavě. U etablovaného autora, jakým byl Franz Schreker, navíc pak ve Vídni, kde klasické zaužívané hodnoty dlouho představovaly nepřekročitelnou estetickou hranici, bylo téměř nemožné komponovat neobvyklými technikami a v systémech, jejichž budoucnost lze jen stěží předvídat. Přesto na jaře 1920 předložil Hába svému učiteli čtvrttónovou kompozici. Schreker ji prý přijal s údivem a zděšením, současně však doporučil skladbu k vydání u Universal Edition. Skladatelův záměr se projevil ve formě vnější a vnitřní vázanosti (formální schéma a důsledné využití motivické práce) a ve způsobu zapracování čtvrttónů. Originalita díla netkví v jeho neobvyklém stylu, ale v materiálovém vybavení. Jak autor uvádí v Předmluvě k tištěné partituře, skladba je dokladem hledání originálního vyjadřovacího jazyka, ve kterém nemají být čtvrttóny překvapivým obratem, nýbrž pouhým domyšlením předchozího vývoje. ${ }^{2}$ Skryté čtyřdílné schéma skladby zasazené do jednověté formy je sjednoceno drobnými rytmickými útvary. Čtvrttónová chromatizace hudebního materiálu pak odpovídá povaze rytmické pulsace, které do díla vnáší vnitřní těkavý neklid. Druhý smyčcový kvartet, který se stal základem volného přechodu k hudebnímu výrazu osvobozené hudby, byl dílem úspěšným. Nic na tom nemění ani Hábovo pozdější odmítnutí koncepce díla, odporující pro jeho motivickou provázanost idejím atematismu.

Zajímavým př́íspěvkem do diskuse kolem způsobu užívání mikrointervalů jsou Hábovy pozdější transkripce. Suity pro violoncello (op. 81a) a housle (op. 81b) byly dokončeny v roce 1953, k jejich přepracování do šestinotónové soustavy (op. 85a, 85b) došlo na jaře 1955. Obě varianty jsou ukázkou Hábova chápání mikrointervalové chromatizace a prozrazují mnohé o způsobech jejího užívání. Pokud budeme šestinotónovou úpravu původního zápisu chápat jako jeho chromatizaci, pak nové tóny přejímají funkcí průchodných jevů (melodických tónů) a dávají vyniknout tónům strukturně významnějším.

2 Viz HÁBA, Alois. Streichquartett im Vierteltonsystem, op. 7. Wien: Universal Edition, 1921. 


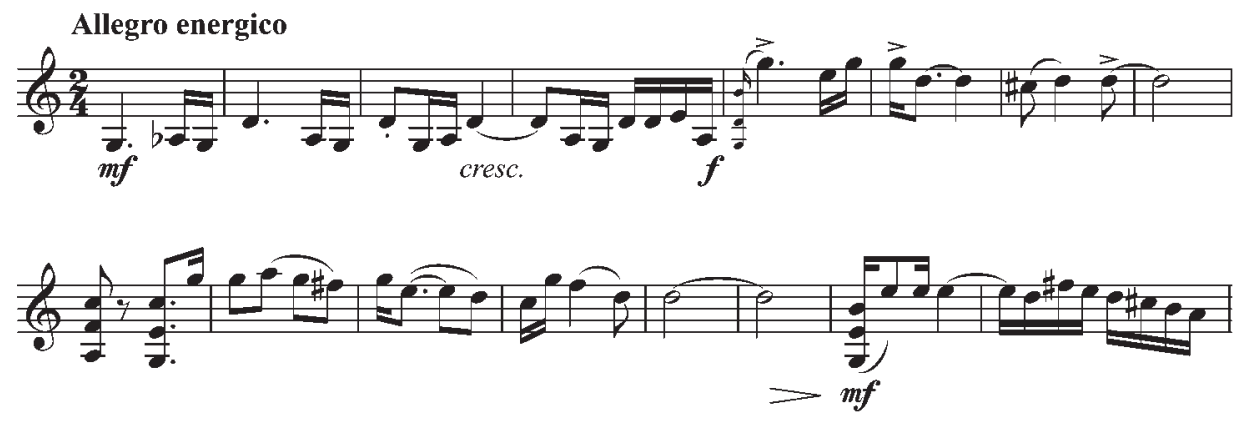

Př. 1 A. Hába: Suita pro housle sólo op. 81b, t. 1-16.

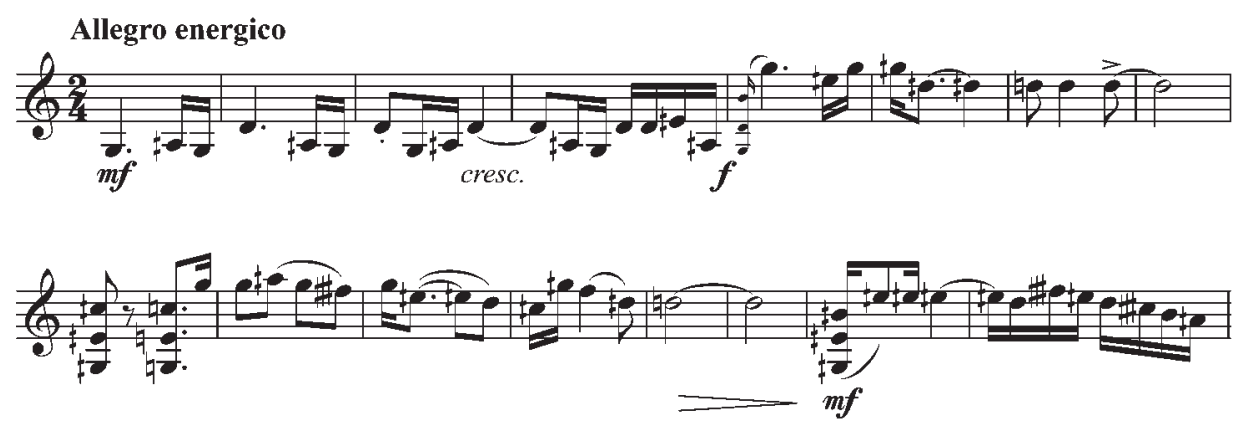

Př. 2 A. Hába: Suita pro housle sólo v šestinotónové soustavě op. 85b, t. 1-16.

2.

Nejen nové tónové systémy (čtvrttóny a šestinotóny), ale především vznik čtvrttónového a šestinotónového instrumentáře výrazně ovlivnil Hábovu kompoziční praxi. ${ }^{3}$ V říjnu 1922 si Hába objednal čtvrttónové harmonium u firmy Straube's Harmoniumbau-Anstalt v Berlíně, jehož cena činila v přepočtu 1200 korun; vzhledem ke skladatelově tehdejší finanční situaci se dá hovořit o skutečné posedlosti. V červnu 1924 pak mohl na pražském festivalu ISCM představit nový čtvrttónový klavír firmy August Förster. Obě události ohraničují krátké období, během kterého se Hába etabloval na respektovaného autora a znalce mikrointervalové hudby.

3 Snad nejdůležitější byl vznik čtvrttónového klavíru. O Hábově podílu na jeho vzniku zevrubně informuje Vlasta Reittererová, viz REITTEREROVÁ, Vlasta: Hudební umění jako realizovaná pravdivost. Podíl Aloise Háby na stavbě a propagaci čtvrttónového klavíru. Hudební věda, 2008, roč. 45 , s. 125-178. 
Nový nástroj skladatele pobízel k čilé kompoziční práci a zvuk čtvrttónového klavíru se např́íště stal nedílnou součástí zvukových představ spojovaných s Hábovou mikrointervalovou hudbou. První čtvrttónové skladby pak vznikly na př́mý popud nakladatelství Universal Edition. Od konce roku 1924 až do července 1926 jich Hába zkomponoval 23, z nichž 14 věnoval čtvrttónovému klavíru. To, že se jednalo o nástroj toužebně očekávaný, dokazuje trojice kompozic z roku 1922, dokončených ještě před vznikem nástroje. (Žádná z nich však neodpovídala autorovým pozdějším nárokům a $\mathrm{v}$ roce 1932 je nahradil skladbami novými.) Možnosti spojené s vytvořením dokonalejší zvukové představy nového tónového systému rovněž rozšírila repertoár jiných nástrojových obsazení. Mezi klavírní Suitou op. 10 (1923) a Fantasií pro violoncello a čtvrttónový klavír op. 33 z konce roku 1926 až na dvě výjimky nevzniklo žádné dílo komponované v tradičním systému. Klavírní skladby tvořil Hába rychle v krátkých zhruba týdenních intervalech, jak dokazují časové údaje zanesené do autografü.

Forma a stylizace klavírních fantazií a suit je výrazně ovlivněna Hábovými př̀dstavami o nové tvůrčí poetice. Formálně zdánlivě beztvaré kaleidoskopické kusy jsou sjednoceny plastickou dynamikou, kontrastními tempy a rytmy, což alespoň zčásti usnadňuje orientaci posluchače $\mathrm{v}$ díle. Pasáže, připomínající krátká technická cvičení s charakteristickými figuracemi, zohledňující mechaniku klavíru, jsou stř́idány prokomponovanými polyfonně pojatými úseky. Ambiciózní plán na vznik takových skladeb uskutečňoval Hába řadu let. Zjevně zamýšlel vytvořit základní literaturu nástroje, využívající jeho technické a výrazové možnosti, a doufal, že nový klavír záhy vstoupí do povědomí odborníků a širšího okruhu milovníků nové hudby.

Hábovy skladby z této doby jsou na mnoha místech prostoupeny kompozičními obraty, jež ve svém důsledku nesou znaky kompoziční šablony. V akordických sledech se např́íklad autor vyhýbá tradičním spojům a postupům, připomínající kadenční model. Ostré disonantní souzvuky bývají často uváděny v sériích paralelně postupujících hlasů. Mimořádnému zájmu se rovněž těší „nový interval“, o čtvrttónu zvětšená velká sekunda, či snížená malá tercie (2.5). ${ }^{4}$ Jeho přitažlivost spočívá $\mathrm{v}$ rovnoměrném rozdělení čisté kvarty na dvě části. Tento interval se pak mnohokrát objeví v podobě melodického průchodného tónu (mezi tóny čisté kvarty), či jako součást akordických paralelních postupů.

Především úvodní části suit a fantasií jsou mnohdy uváděny melodiemi s dlouhou lineární linkou, či pregnantně artikulovanými jednohlasými tématy (popř. oktávově zdvojenými či využivajícími skrytý vícehlas). Navzdory improvizačnímu charakteru se zde autor pokouší vymezit jejich vnitřní členění prostřednictvím opakovaných návratů $\mathrm{k}$ centrálním tónům (tónovým či intervalovým centrům) (Př̀. 3 tón ces; př. 4 tóny $g$, zvýšené $a$ ) 
Allegretto
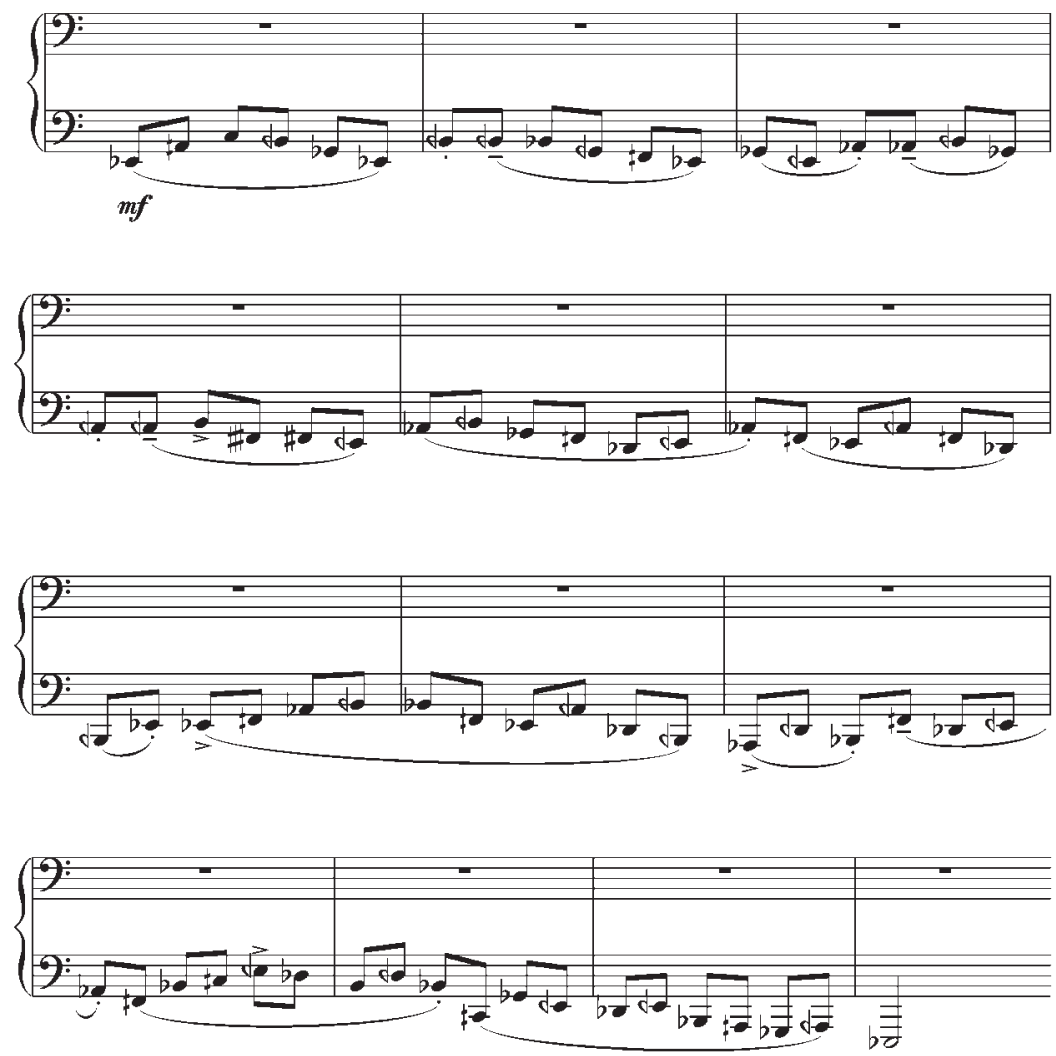

Př. 3 A. Hába: Fantasie č. 10 op. 31, t. 1-13.
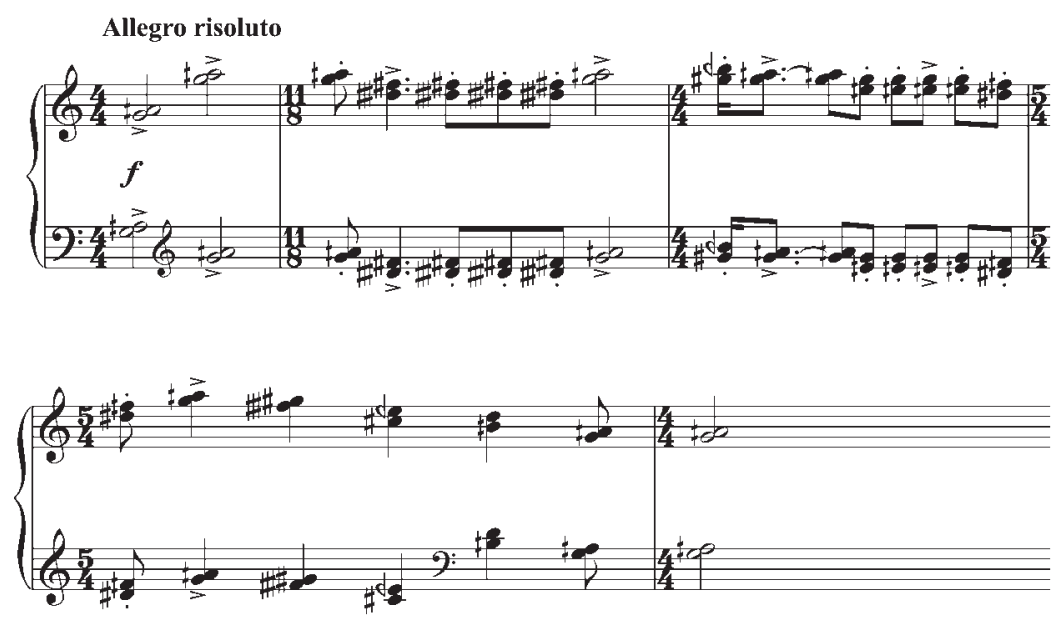

Př. 4 A. Hába: Suita č. 1 op. 10, t. 1-5. 
3.

Téměř od počátku tvůrčí dráhy doprovázel Hába své znějící dílo rozličnými texty, jimiž se pokoušel reflektovaně nahlížet na vlastní tvorbu. V souboru textů různé úrovně a zaměření si dodnes uchovaly svůj význam Hábovy hudebně teoretické studie Diatonický, chromatický a bichromatický zvuk v hudbě evropské (1930/31), Harmonické základy dvanáctitónového systému. Tematický a netematický hudebni sloh (1937/38) a knižní publikace Harmonické základy čtvrttónové soustavy (1922), O psychologii tvoření, pohybové zákonitosti tónové a základech nového hudebniho slohu (1925) a Neue Harmonielehre des diatonischen, chromatischen, Viertel-, Drittel-, Sechstel- und Zwölfteltonsystems (Nová nauka o harmonii diatonické, chromatické, třetinotónové, šestinotónové a dvanáctinotónové soustavy, 1927).

Syntézu těchto názorů nalezneme v Nauce o harmonii diatonické, chromatické, čtvrtinotónové, třetinotónové, šestinotónové a dvanáctinotónové soustavy (1942-1943); autograf česky psaného textu byl v roce 2007 vydán německy jako Harmonielehre des diatonischen, chromatischen, Viertel-, Drittel-, Sechstel- und Zwölftel-Tonsystems (1942-1943). ${ }^{5}$

Doba vzniku publikací dokazuje, že snaha uchopit technologii tvorby či kompoziční postupy, vystihnout jejich zobecňující ráz a srozumitelně je převyprávět širšímu okruhu čtenářŭ, souvisí s Hábovou pedagogickou činností na Pražské konzervatoři. Snahu po sebevyjádření mechanismů vlastní tvorby sice můžeme objevit rovněž $\mathrm{v}$ jiných autorových dokumentech, přesto pouze $\mathrm{v}$ přibližně dvacetiletém období (1922-1942/43) jsou Hábovy texty jednoznačně orientovány na hudební teorii, resp. na obor, který souvisí s konvenčním určením tohoto předmětu.

První teoretické práce měly vysvětlující a zdůvodňující charakter. Mnohé z názorů, které se v nich objeví, zachycují obraz hudby osvobozené od architektonických či estetických dogmat. Autor v nich usiluje o adaptaci základních tezí „osvobozené hudby“, vycházejících z vlastní kompoziční praxe, do centra pozornosti se proto dostávají především mikrotonalita, atematismus, později modalita a historické souvislosti, jež vedly k jejich vzniku. V těchto př́ípadech využívá myšlenek cizích autorů, i když ve výběru značně redukovaném a mnohá fakta pak přizpůsobuje aktuálním potřebám. Počínaje Novou naukou o harmonii, kdy Hábovo sebevědomí posílila řada realizovaných skladeb, byla obrana osobitého kompozičního stylu doplněna výkladem technických postupů. Namísto proč?, tedy autor odpovídá na otázku jak?;

5 Rukopis práce Hába dokončil pravděpodobně během školního roku 1942-43. Další úpravy textu pak byly provedeny ještě v létě následujícího roku, jak o tom svědčí stručná poznámka v autografu Pěti milostných písní lidových z Moravy pro střední hlas op. 58. Česky psaný autograf Hábovy práce, jenž je uložen v Českém muzeu hudby v Praze, je tvořen třinácti sešity formátu $20 \times 14 \mathrm{~cm}$ a obsahuje vedle notových ukázek poznámky estetizujícího a hudebně teoretického zaměření. Péčí Jiřího Vysloužila byl rukopis připraven k českému vydání. Pod vedením Horsta-Petera Hesseho, jenž je uveden jako editor, práci připravili ke konečnému vydání Kai Bachmann a Wolfgang Thiese. Nakladatel usoudil, že jazyk originálu bude jen stěží hledat svého čtenáře a proto, s pomocí německého překladu Věry Vysloužilové, posunul text blíže tradici, k níž práce svým způsobem odkazuje. 
zdůvodnění volby tónových systémů a technik je nahrazeno popisem prostředků, s jejichž pomocí je výsledku docilováno.

Jedním z důležitých momentů Hábovy teorie, jenž se nejjasněji objevuje v Neue Harmonielehre, je zdůrazněný význam stupnice a řady. ${ }^{6}$ Když o nich Hába hovoř́i (řady o pěti, šesti či jedenácti tónech), vysvětluje jedním dechem vlastní, poněkud specifické pojetí tonality, vylučující př́padnou atonalitu: každý kus je tonální, nebot' jeho zvukový materiál je za všech okolností součástí řady. Pomineme-li důležitý fakt, že Hábou uvažovaná tonalita nemá nic společného s běžně chápanou harmonickou tonalitou, stávají se stupnice a řady jedním z nosných témat Hábovy učebnice.

Přestože podobnost se Schönbergovou kompozici s dvanácti tóny se zdá být vzdálená, směruje řada odkazů právě $\mathrm{k}$ tomuto autorovi a $\mathrm{k}$ jeho kompoziční

\section{Allegretto scherzando}
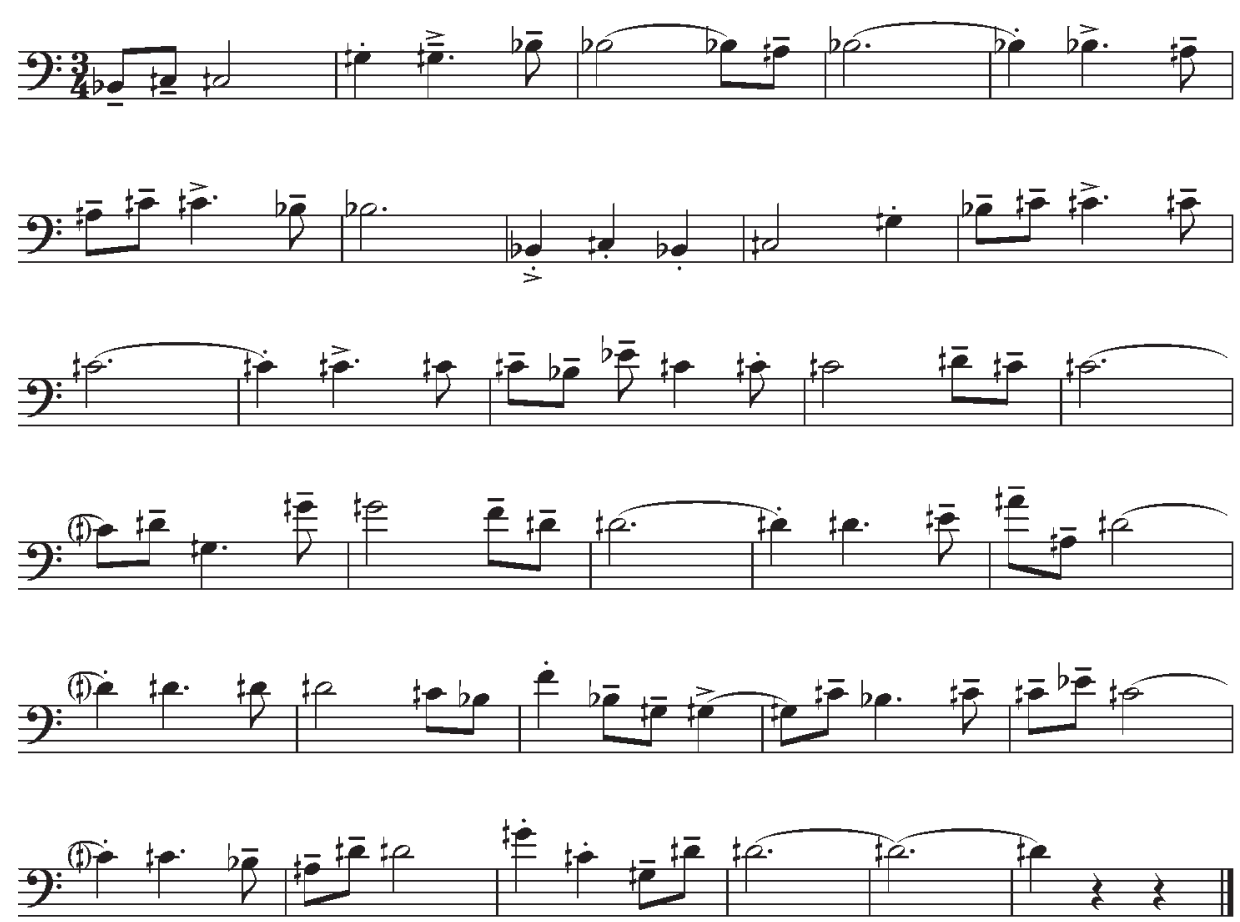

Př. 5 A. Hába: Suita pro čtyři pozouny op. 72, 3. věta.

6 Podobně je tomu rovněž v Harmonielehre Bruno Weigla. V poválečném období pak podobný typ zkoumání tvoří jednu z charakteristických oblastí domácí teorie. K tomu např.: HERZOG, Eduard. Úplný rejstř́k dvanáctitónových všeintervalových řad. In Nové cesty hudby I. Praha - Bratislava: SHV, 1964, s. 109-135; KAPR, Jan. Konstanty. Praha - Bratislava: Panton, 1967; PIŇOS, Alois - HERZOG, Eduard - JAN, Jiří. Vyvážené intervalové řady. Nové cesty hudby II. Praha - Bratislava: SHV, 1970, s. 86-182; PIŇOS, Alois. Tónové skupiny, Praha: Supraphon, 1971. 
práci. ${ }^{7}$ Hába nevynechá jedinou př́ležitost, aby nezmínil podobnost vlastních nových řad se základním tvarem (Grundgestalt).

Uplatňování tohoto principu je Hábou přiznáno v autografu čtvrttónových Pěti sborů pro dětské nebo ženské hlasy op. 42, ve kterém je každý ze sborů na závěr doplněn výchozí tónovou řadou. $V$ jiných př́padech je jeho užití demonstrováno méně otevřeně, jako např́klad ve vrchním hlase (první pozoun) třetí věty Suity pro čtyři pozouny op. 75 (1950).

Melodická linka věty je tvořena symetrickou devítitónovou řadou složenou ze dvou intervalově shodných tetrachordů $(2.5,2.0,0.5)$, rozdělených uprostřed tónem $\neq$ E. Tón, jenž není součástí žádného ze dvou tetrachordů navíc zazní pouze jednou (t. 19).

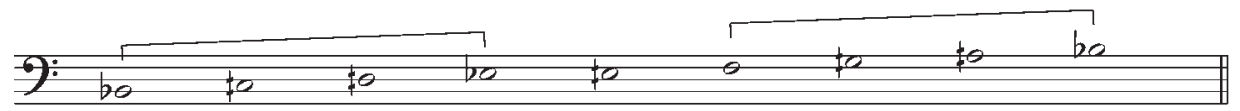

Př. 6

4.

Hába rovněž upozorňuje na možnost, že tradiční tonálně harmonické vztahy mohou být doplněny novými pravidly. $\mathrm{V}$ tomto ohledu sehrává významnou roli tzv. tónová centralita (Tonzentralität). Jiř́i Vysloužil ji považuje za klíčový princip Hábovy kompoziční práce, jenž dává jeho hudbě specifický řád, diametrálně odlišný od Schönbergovy př́isné práce s dvanácti tóny. ${ }^{8}$ Hába zde přichází s vlastním řešením organizace dvanáctitónového materiálu, které pojal na zásadě vztažnosti tónů a souzvuků $\mathrm{k}$ jednomu tónovému centru. Jedná se o druh faktury, ve které je centrum uváděno jinými než harmonickými prostředky. Rovněž v tomto př́ípadě má tón jako vztahové těžiště funkční význam centrálního akordu (tóniky) a tato role je vyjádřena poměrem k okolním akordům a tónům.

Převedeno do jazyka Hábovy teorie to znamená, že jakýkoliv akord je na každém stupni chromatické řady možný a tento stupeň (tón) se stává pro př́íslušné akordy tónovým centrem; nebo také, že ke každému tónu řady lze vztahovat všechny tóny zbývající. V pozdějších textech Hába tuto možnost rozšiřuje. Tónovými centry nemusejí být pouze jednotlivé tóny, nýbrž „tónové shluky“, které hlavní tón doplňují o malou sekundu.

Přestože tónová centralita má vyjádřit autorovo pojetí „nové tonality“, nemusí výklad akordických skupin z hlediska centrálního tónu rušit tradiční tonální vztahy. I když centralita může významně působit na místech, kde jsou tonální vztahy zeslabeny, není míra tonálnosti zkoumané skladby nepř́ímo úměrná zastoupení

7 Skutečnost, že Hába hovoří o Schönbergově ,přisné práci s dvanácti tóny“ již v roce 1927 (resp. 1925), jej řadí k prvním domácím autorům, kteří se s touto praxí vyrovnávali. 
tónové centrality. Tónová centralita jako způsob nahlížení na hudební strukturu je $\mathrm{v}$ jistém smyslu pomocným řešením, které má dokázat vnitřní spojitost mezi vzdálenými harmoniemi. Zavedení tohoto principu bylo motivováno snahou vyložit složitější harmonické jevy přehledným způsobem. Tónová centralita zjednodušuje poměrně komplikovanou argumentaci, týkající se alterací či některých průběžných harmonií, které vznikají jako důsledek vedení hlasů.

Můžeme se ptát, jakým způsobem vstupuje tónová centralita do Hábových skladeb. Je zřejmé, že Hába tento vztah neuplatňuje absolutně, ani zde tónová centralita nesehrává roli jednoznačně upotřebitelného principu. Ve vztahu k jiným řešením se rovněž zde jedná o vztah komplementarity, kdy různé faktury a techniky se odstupňovaně střídají. Různou míru uplatnění však nachází ve většině autorových skladeb, počínaje Sborovou suitou op. 13 (1923).

Můžeme se ptát, jaké výhody pro hudební analýzu tónová centralita nabízí. I když autorovou snahou bylo vytvořit obecný analytický model, není doslovně chápaná tónová centralita aplikovatelná na díla jiných autorů, dokonce ji nelze využít ani na některá díla Hábova. Na rozdíl od harmonických teorií a analytických postupů je spíše jedinečným kompozičním řešením. Naopak analytický aparát nauky o stupních (Stufenlehre, Stufenbezeichnung), funkční teorie (Funktionstheorie) či Schenkerovy nauky o vrstvách (Schichtenlehre) má schopnost formalizovat znakové procesy, čímž se stává vhodným nástrojem k popisu a interpretaci širokého spektra skladeb. Zmíněné teorie však nejsou a ani nemohou být kompoziční metodou, ba ani neslouží k pomyslnému rozpoznání autorského záměru.

V některých skladbách ovšem centrální tón sehrává úlohu podpůrného hlasu, jenž usnadňuje interpretaci díla. Za př́klad mohou posloužit sborové cykly, které Hába zkomponoval v rychlém sledu o letních prázdninách roku 1932: Pět sborů pro dètské nebo ženské hlasy ve čtvrttónové soustavě op. 42, Sborové dětské hry. Šest sborů pro sólový hlas a čtyřhlasý dětský sbor ve čtvrttónové soustavě op. 43, Pět smíšených sborů ve čtvrttónové soustavě op. 44, Pracující den. Deset mužských sborư ve čtvrttónové soustavě, op. 45. Tři z nich vycházejí z textů Nezvalova Skleněného haveloku, čtvrtý je pak složen na slova básnické sbírky Josefa Hory Pracujici den. O obtížnosti uvedených cyklů, plných neobvyklých harmonických postupů, svědčí také skutečnost, že žádný z nich nebyl dosud proveden. Autor v nich potlačil moment kreativního zpracování a omezil se na holé konvenční postupy, jež mají povahu quasi strukturních schémat (modelů). ${ }^{9} \mathrm{Kom}-$ poziční záměr navíc prozrazují harmonické komprimované plány či př́islušné tónové řady, prripsané autorem na závěr každé ze sborových vět. Takové řešení pak usnadňuje naši orientaci v díle a poskytuje určitý návod $\mathrm{k}$ jeho nácviku.

Jak dokazuje následující schéma, ve sboru Týdenni hry, jenž je prvním číslem cyklu Sborové dětské hry, postupují střední hlasy v paralelních kvartách rozdělených intervalem o čtvrttón zvětšené velké sekundy či zmenšené malé tercie (2.5)

Pojem strukturní schéma, lineární model (Satzmodel, pattern) se začíná od osmdesátých let 20. století častěji objevovat v hudebně teoretických textech. Jedná se soubor konvenčních postupů, který není vázán na konkrétní tvůrčí poetiku autora. Srov. SPURNÝ, Lubomír. Heinrich Schenker (1868-1935). Kapitoly z hudebni teorie a analyzy. Praha: KLP, 2012, s. 90-94. 
na dvě shodné poloviny. Tento trojzvuk patří $\mathrm{k}$ jednomu $\mathrm{z}$ nejobvyklejších tvarů Hábovy akordiky. Popsaný postup alespoň z části dokumentuje význam kvartových akordů v autorově pojetí „,nové harmonie“. Výrazným znakem tohoto užití je rovněž tón $C$ ve spodním hlase, který je oporou harmonického pohybu a plní funkci tónového centra.

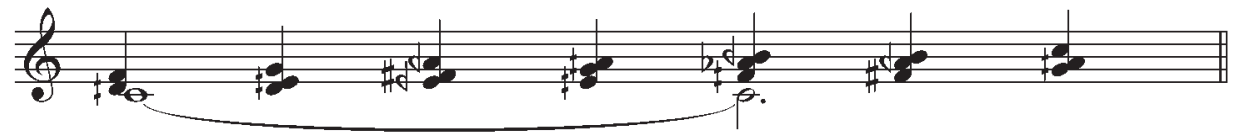

Př. 7 A. Hába: komprimované schéma sboru Týdenni hry z cyklu Sborové dètské hry.

Princip tónového centra platí rovněž pro melodii. Ve sboru Čísla se v takové funkci objeví tón $E \mathrm{v}$ nižším tenoru. $\mathrm{V}$ linii sólového hlasu je pak význam tohoto tónu zohledněn častými návraty.
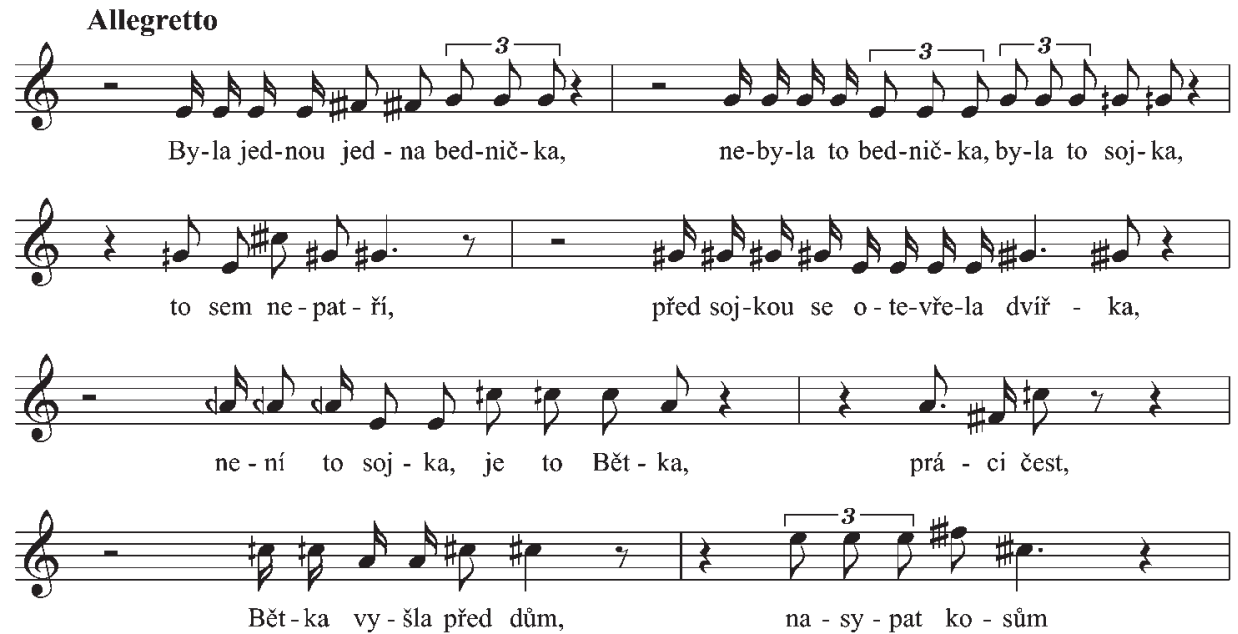

Př. 8 A. Hába: Čisla z cyklu Sborové dětské hry.

Další specifické pojetí melodizace nalezneme ve sboru Znamení. V komprimovaném schématu harmonického plánu lépe vyniknou paralely zvětšených kvintakordů, jež jsou doprovázeny protipohybem spodního hlasu.

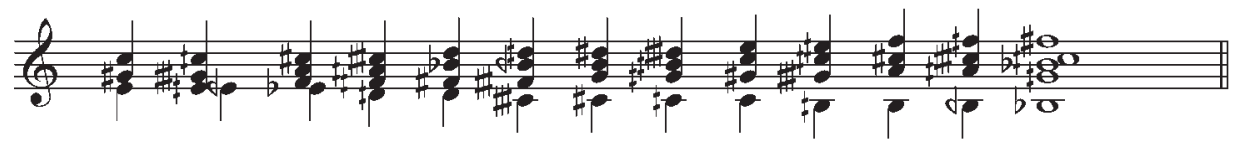

Př. 9 A. Hába: Znameni z cyklu Sborové dětské hry. 
5.

I když po válce Hába neopustil možnost komponovat v různých tónových systémech a opětovně se vyrovnával s podněty dodekafonie a webernovského serialismu, nebylo toto období obecně spojováno s hledáním žánrové novosti a s návraty, třebas i opožděnými, avantgardních stylů. Dočasná expanze angažovaného umění po jistou dobu způsobila, že některé představy o celkovém uspořádání díla a jeho funkcích přsšly i do následující tvorby. Především na počátku tohoto období komponoval Hába způsobem, jenž směřoval k redukci a zjednodušení. Přes podobná tvrzení však měla tato tendence důkladné kompoziční zázemí. Bez něho, bez tradice předchozích děl a jasných představ o výsledném znějícím tvaru, by patrně podobný druh produkce směřoval $\mathrm{k}$ banalitám. Př́kladem takového řešení může být čtvrttónová Suitu pro čtyri pozouny.
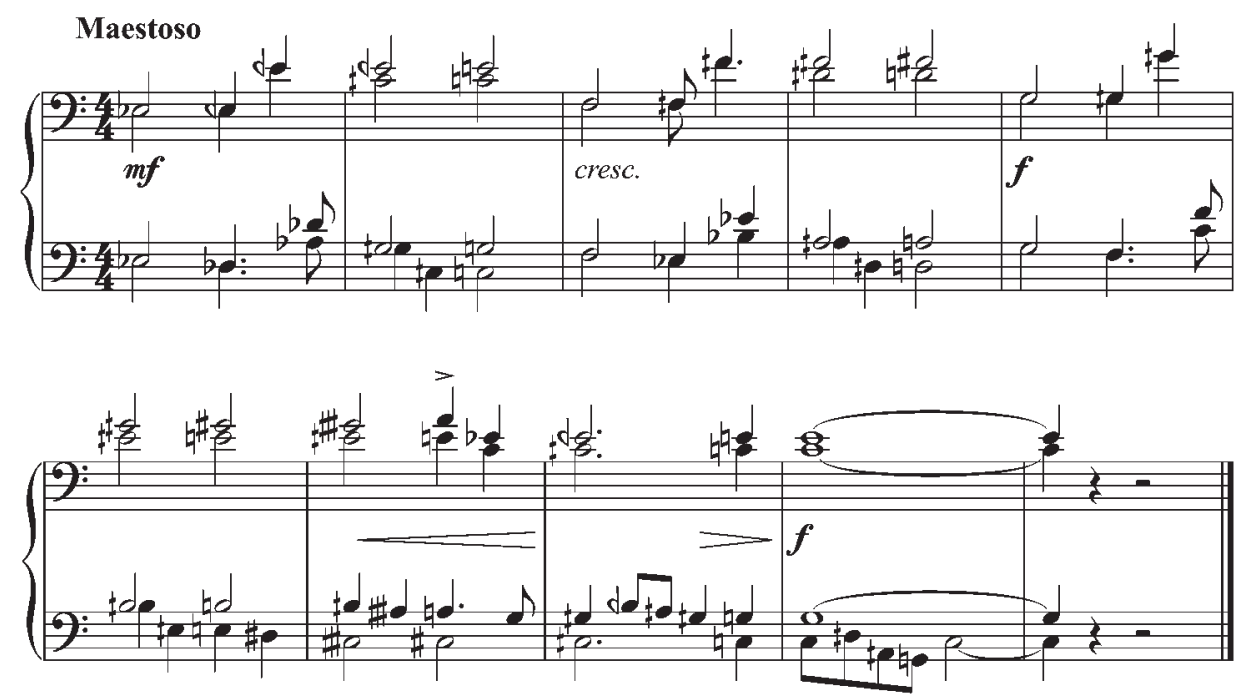

Př. 10 A. Hába: Suita pro čtyři pozouny op. 72, 1. Věta.

Rytmická redukce, zobrazující vedení hlasů, odkrývá čtvrttónové chromatické útvary, které v protipohybu vrchního a spodních hlasů skladbou prostupují. Místa jejich začátků a závěrů se shodují s nástupem tradičních akordů či jejich fragmentů, které tvoří pevné harmonické vazby ([C] es, C, D, G, E, C) Takto nahlíženo, působí chromatický pohyb čtvrttónových akordů jako průběžné harmonie v rámci tradičně utvářeného schématu tonální kadence.

Závěrem krátká poznámka. Hábovy mikrointervalové kompozice, které byly živou součástí meziválečných hnutí a směrů, v padesátých a šedesátých letech viditelně zestárly. Důvody podobných konstatování vycházejí ze způsobu posuzování historického významu hudební moderny. Zaměřme-li svoji pozornost 

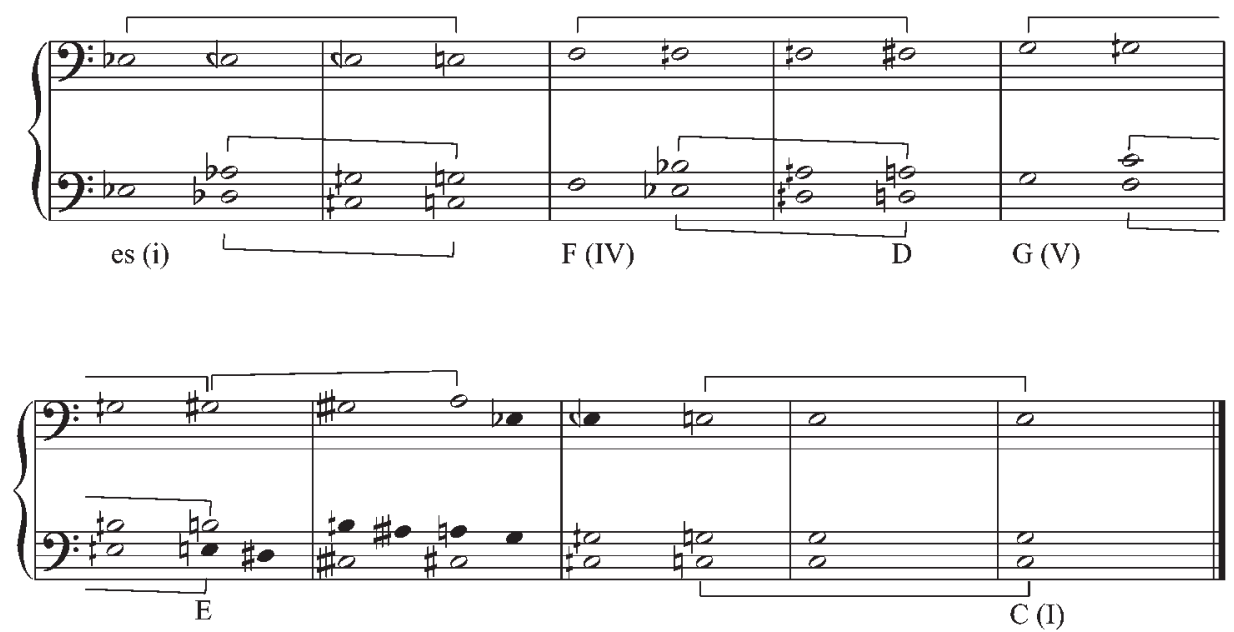

Př. 11 A. Hába: Suita pro čtyři pozouny op. 72, 1. věta, rytmická redukce.

na důležité vývojové momenty, zatlačíme nutně vše ostatní do pozadí. V atematické a mikrointervalové hudbě se výrazně prosazují některé postupy, které analogicky s technickými inovacemi či vynálezy v dalších generacích nutně zastarávají.

Studie vznikla v rámci plnění projektu Center for Research on the Works of Alois Hába: Editing of the Correspondence of Alois Hába in the Czech Museum of Music (GAČR, registrační číslo 408-09-0404).

Lubomír Spurný (spurny@phil.muni.cz) (1965) působí na Ústavu hudební vědy Filozofické fakulty Masarykovy univerzity v Brně. Oblastí jeho zájmu je teorie a estetika novější hudby.

\section{ABSTRACT \\ HÁBA MICROTONAL: FIVE NOTES TO HÁBA'S COMPOSITIONAL STYLE}

The article is a critical interpretation of selected microtonal compositions of the Czech composer Alois Hába. The author focused his attention on the chamber and choral compositions opp. 7, 10, $27,31,43,72$.

In the general perspective of music history, Alois Hába is usually characterised as one of the leading protagonists of the Central European inter-war avant-garde that moved between Vienna, Berlin and Prague. In the specific context of Czech music he likewise has the reputation of an exemplary innovator but is considered to have been strongly rooted in tradition as well. Hába is known primarily as a tireless propagator of microtonal and athematic music, for which his own term was "liberated music". In this music he added more subtle quarter-, fifth- and sixth-tone intervals to the semitone system and abandoned up traditional treatment of motifs. These mere assertions, however, do not of themselves have any precise content and in fact problematize any proper conception of 
Hába's music; for example, pieces composed with microtones in fact represent less than a third of Hába's output as a composer.

\section{Key words}

Alois Hába, Czech music, quarter-tone music, athematism, music theory

\section{Bibliography}

HÁBA, Alois. Harmonické základy čtvrttónové soustavy. Praha: HMUB, 1922.

HÁBA, Alois. Neue Harmonielehre des diatonischen, chromatischen Viertel-, Drittel-, Sechstelund Zwölftel-tonsystems, Leipzig: Kistner \& Siegel, 1927; česky Nová nauka o harmonii diatonické, chromatické, třetinotónové, šestinotónové a dvanáctinotónové soustavy. Přeložil Eduard Herzog. Jinočany: H\&H, 2000.

HERZOG, Eduard. Úplný rejstřík dvanáctitónových všeintervalových řad. In Nové cesty hudby I. Praha - Bratislava: SHV, 1964, s. 109-135.

KAPR, Jan. Konstanty. Praha - Bratislava: Panton, 1967.

PIŇOS, Alois - HERZOG, Eduard - JAN, Jiří. Vyvážené intervalové řady. Nové cesty hudby II. Praha - Bratislava: SHV, 1970, s. 86-182.

PIŇOS, Alois. Tónové skupiny. Praha: Supraphon, 1971.

REITTEREROVÁ, Vlasta - SPURNÝ, Lubomír. Alois Hába. In Komponisten der Gegenwart. Hans Werner Heister - Walter Wolfgang Sparrer (eds.). München: Boorberg, 2009, s. 1-50.

REITTEREROVÁ, Vlasta. Alois Hába - Experimentator oder Eklektiker? In Littera Nigro scripta manet. In honorem Jaromír Černý. Jan Bat'a - Jiř́ K. Kroupa - Lenka Mráčková (eds.). Praha: KLP, 2009, s. 178-206.

REITTEREROVÁ, Vlasta. Hudební umění jako realizovaná pravdivost. Podíl Aloise Háby na stavbě a propagaci čtvrttónového klavíru. Hudební věda, 2008, roč. 45, s. 125-178.

SPURNÝ, Lubomír. Harmonie v nesnázích. Několik poznámek k Hábově Neue Harmonielehre. Hudební věda, 2007, roč. 44, s. 261-288.

SPURNÝ, Lubomír. Heinrich Schenker (1868-1935). Kapitoly z hudební teorie a analýzy. Praha: KLP, 2012.

VYSLOUŽIL, Jiří. Alois Hába. Život a dílo. Praha: Panton, 1974.

VYSLOUŽIL, Jiř́. Hába's Idea of Quarter-tone Music. Hudební věda, 1968, roč. 5, s. 466-472.

VYSLOUŽIL, Jiří. Hábova hudba pro čtvrttónový klavír. Opus musicum, 1973, roč. 5, s. 101-107. 
